The 16th Economic International Conference

New Challenges and Opportunities for the Economy 4.0, May 7-8th, 2020, Suceava, Romania

\title{
Integrated Reporting - A New Management Tool in Analyzing the Performance of a Company
}

\author{
Simona-Maria TANASĂ (BRÎNZARU)
}

https://doi.org/10.18662/lumproc/ncoe4.0.2020/06

How to cite: Tanasă (Brînzaru), S.-M. (2020). Integrated Reporting - A New Management Tool in Analyzing the Performance of a Company. In C. Nastase (vol. ed.), Lumen Proceedings: Vol. 13. 16th Economic International Conference NCOE 4.02020 (pp. 57-69). Iasi, Romania: LUMEN Publishing House.

https://doi.org/10.18662/lumproc/ncoe4.0.2020/06 


\title{
Integrated Reporting - A New Management Tool in Analyzing the Performance of a Company
}

\author{
Simona-Maria TANASĂ (BRÎNZARU) ${ }^{1} *$
}

\begin{abstract}
Integrated reporting is currently the newest form of corporate reporting that is in the process of being developed and adopted by companies around the world. Integrated reporting is the answer to the many requirements related to reporting non-financial information and their connectivity with financial information and different approaches to performance. The main objective of this research is the analysis of the performance of the companies that have adopted the integrated reporting, according to the specific business sector, through the profitability indicators. To achieve this goal, we created a sample of companies operating in Europe, North and South America, over 2015-2017. The result of the research reflects that the adoption of integrated reporting does not represent a significant influence factor on the profitability of the analyzed business sectors which will certainly lead to the increase of the performance over time. Integrated reporting is a management tool that must be used appropriately to gain maximum benefits both in the performance of a company and in corporate reporting.
\end{abstract}

Keywords: integrated reporting; profitability; performance; managerial decisions.

1 Department of Accounting, Audit and Finance, Faculty of Economic Sciences and Public Administration, "Stefan cel Mare" University, Suceava, Romania, tanasasimona19@yahoo.com 


\section{Introduction}

Integrated reporting (IR) is a relatively new concept but it has a long story behind it. Starting from traditional financial reporting with its limitations to sustainability reporting, corporate reporting has evolved to meet the information needs of stakeholders and changes in the global economy. Moreover, the concept of IR first appeared in practice and then was developed theoretically and developed a framework for this new type of reporting.

Thus, we find integrated reporting in the practice of companies since 2002. The companies Novozymes and Natura (2002), Novo Nordisk (2004) were among the first to experience the creation of a single report that shows the link between sustainability and corporate performance having the benchmark issued by GRI in 2000. Examples were followed by Philips and United Technologies Corporation in 2008. [10]

South Africa played an important role in the sector of integrated reporting by publishing the King I Report (1994), King II (2002) and King III (2009) through the King Committee. The latest IR adoption report became mandatory in 2010 for all companies listed on the Johannesburg Stock Exchange (JSE). In January 2011, the South African Integrated Reporting Committee (IRCSA) published the world's first IR framework, called the „Integrated Reporting Framework and Integrated Report: Consultative Framework", which was also the base for IIRC. [7]

In 2010, International Integrated Reporting Council (IIRC) was set up following a meeting between the British organization „The Prince of WalesAccounting for Sustenability Project" and GRI, with the role of developing a conceptual framework for integrated reporting. After completing a pilot program, IIRC developed in 2013, a conceptual framework on IR that is still used by large companies. [6]

IIRC argues that integrated reporting promotes a more coherent and efficient approach to corporate reporting and aims to improve the quality of information available to financial capital providers to enable more efficient capital allocation. [11]

IR is a form of voluntary corporate reporting, which means that the decision is made by managers at the level of each company and IIRC admits that managers still have an important word to say in the disclosure of strategic information and prospective information, as they invoke potential costs of litigation and risks losing the competitive advantage of companies. [5] 
So how does IR influence the managerial decision-making process in analyzing a company's performance? These questions determined us to analyze the performance of the companies that apply the integrated reporting, according to the business sector, through the main profitability indicators.

\section{Problem Statement}

Most of the studies found in the international literature focus on factors that influence the decision of companies to adopt integrated reporting, on the compliance of the reports published by companies with the international framework on the reporting from IIRC and on their quality, on the credibility or asymmetry of the information but there is fewer studies related to the relationship between IR and the performance of a company or other perspectives of financial implications.

The study of [13] presents the link between integrated reporting and integrated performance (financial, social, environmental and governance). The conclusions are that in voluntary regimes, the levels of integrated performance achieved by companies are higher and integrated performance shows significant improvements in the years of mandatory adoption of integrated reporting, with effects that intensify in the medium term. Although, according to [15], there is more support for voluntary approaches to integrated reporting, as the various stakeholders who participated in the interview consider it too early for regulatory reform. At the same time, the companies support the voluntary adoption of IR because it leads to its spread more and eventually it will become a reporting norm and a quarter of the interview participants already support a combination of mandatory and voluntary regulatory mechanisms for IR.

Analyzing the 102 integrated reports in Europe, authors found that the intellectual capital disclosure (ICDs) are mainly discursive, with a backward orientation and focus on human capital. But as the optimistic tone of firms' ICDs increases, so does the non-financial performance measured in terms of environmental, social and governance issues. [2]

Another study shows that the performance of ESG (environmental, social and corporate governance) is evaluated more strongly in the positive (desired) direction when firms publish an ESG report, regardless of its type (self-employed or integrated). In addition, integrated reporting is associated with higher results, compared to a standalone report for ESG composite performance and corporate governance. [14] 
The aims of stud ay were identification the „learning effects” in the IR sector on the performance and reporting practices of companies. Following the analysis of the reporting practices and the performances of the companies included in the Pilot Program of the International Integrated Reporting Council for the years 2013 and 2016, the obtained results showed improvements in the performance and diversification of the indicators presented in the reports. However, the changes are not attributable only to integrated reporting; reporting experience is also a contributing factor. [1]

Therefore, the relationship between the performance of a company and the IR should be analyzed more carefully, from several perspectives so that the contribution of IR in improving the performance is clearly highlighted, especially since in the framework IIRC are not included a set of indicators that allow, easily, understanding the integrated performance of a company.

\section{Research Questions/Aims of the research}

The main objective of this research is the analysis of the performance of the companies that have adopted integrated reporting, according to the specific business sector, in terms of profitability. The management of a company plays an essential role in the implementation of the integrated reporting concept because its decisions can lead to the understanding and correct implementation of the IR or not, exceeding the declarative level and at the same time improving the activity of the company.

Thus I advanced the following hypothesis: The companies that have adopted the IR present an improvement of the analyzed performance through the profitability indicators.

\section{Research Methods}

The sample included in this research comprises 50 companies with different activity objects out of the 214 presented through [12] (see http://examples.integratedreporting.org/home), companies that have adopted the principles of integrated reporting. The sample includes companies from three continents in South America, North America and Europe that have published integrated reports according to the framework elaborated by IIRC fully adopted or reports which refer to this framework for the years 2015 to 2017. We excluded all companies that applied the IR framework according to KING III. The companies in the sample are presented according to the business sector in the figure 1 . 


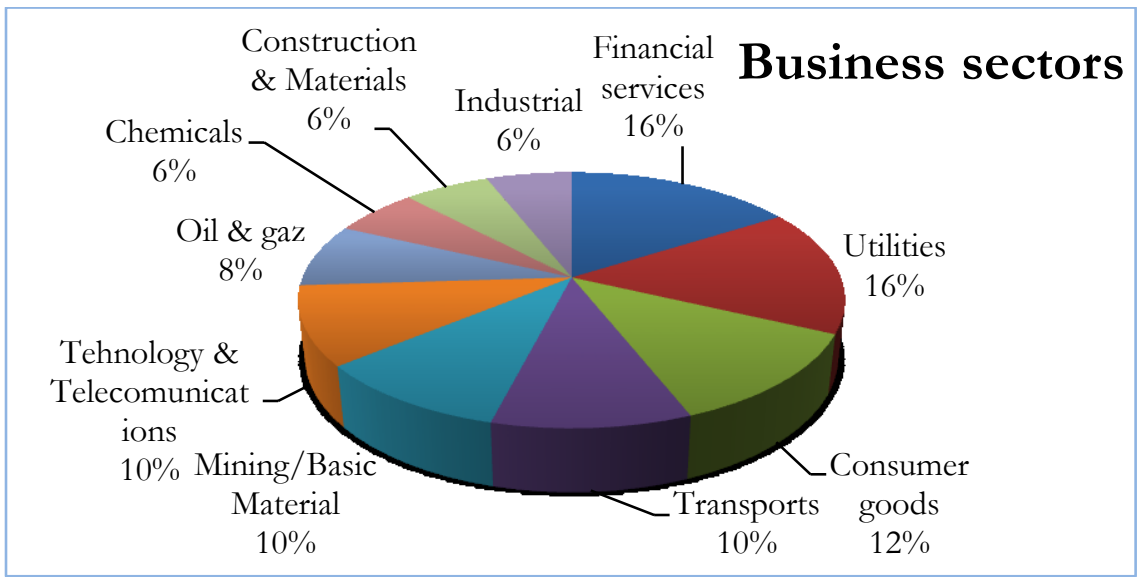

Figure 1: Classification of the companies in the sample according to the business sector *source: own elaboration;

The accounting data were taken from the integrated reports and the consolidated financial statements available on each company's website through the IR Examples Database and subsequently profitability indicators were calculated in Microsoft Excel 2010. The data taken from the financial statements presented in a currency other than the euro have were transformed as such using the National Bank of Romania exchange rate for the end of December of each year. The profitability indicators were calculated for each company separately and then, an average of them was determined for each business sector presented in figure 1. The calculation formulas used in the analysis are presented in table 1.

Tabel 1: The indicators used in the analysis

\begin{tabular}{|c|c|c|c|c|}
\hline $\begin{array}{l}\text { Categor } \\
y\end{array}$ & No & Indicators & Formula & Optimal parameters \\
\hline \multirow{5}{*}{ 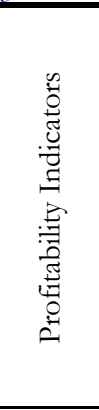 } & 1 & Gross commercial profit rate (Rch) & $\frac{O R}{C A} \times 100$ & Minimum $1.8 \%$ \\
\hline & 2 & Net commercial profit rate (Rcn) & $\frac{N P}{C A} \times 100$ & - \\
\hline & 3 & Return on assets (ROA) & $\frac{N P}{T A} \times 100$ & - \\
\hline & 4 & Return on invested capital (ROIC) & $\begin{array}{l}\frac{O R}{I C} \times 100 \\
I C=P C+C D\end{array}$ & - \\
\hline & 5 & Return on equity (ROE) & $\frac{N P}{P C} \times 100$ & $\begin{array}{l}\text { Minimum } \\
\text { optimum } 25 \%\end{array}$ \\
\hline $\begin{array}{l}\text { Notati } \\
\text { ons }\end{array}$ & \multicolumn{4}{|c|}{$\begin{array}{l}\text { OR - opereting result; CA - turnover; NP - Net profit for the year; TA - total assets; } \\
\text { IC - invested capital; PC - permanent capital; CD - current debts; }\end{array}$} \\
\hline $\begin{array}{l}\text { Purpo } \\
\text { se }\end{array}$ & \multicolumn{4}{|c|}{$\begin{array}{l}\text { Determining and explaining the evolution of each indicator separately on the business } \\
\text { sector, in order to establish a trend. }\end{array}$} \\
\hline
\end{tabular}

*source: own elaboration after [3]; 


\section{Findings}

Integrated reporting involves an integrated vision on a company's strategy and objectives, on the whole activity and on the reporting mode, implicitly on the way of understanding, achieving and presenting the performance. IR provides integrated information (financial and nonfinancial) with the role of supporting stakeholder decision-making and managers should take advantage of this information to streamline the company's internal activity which is reflected in profitability indicators as IR includes external benefits, but also internals that, in fact, are less pronounced. [4], [9], [8]

In order to test the advanced hypotheses, I followed the ascending evolution of each profitability indicator in part over 2015 to 2017, using an average of these on the 10 business sector presented in table 1 .

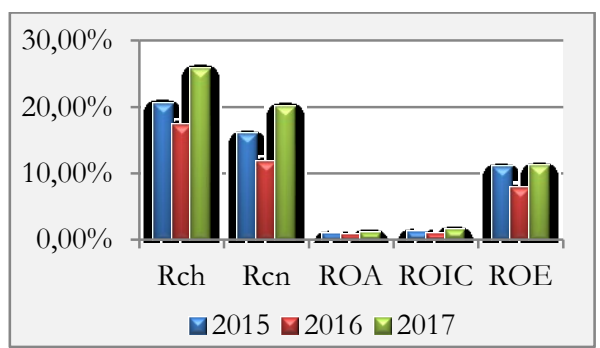

Figure 2: Financial services

*source: own elaboration

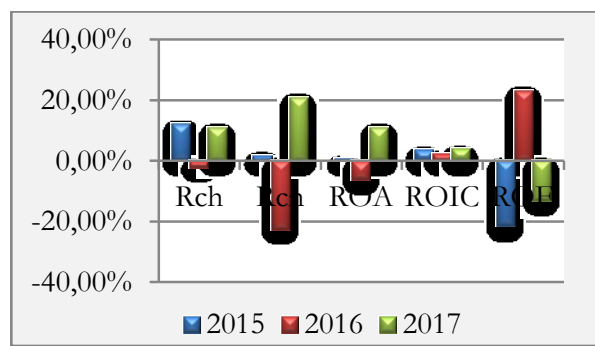

Figure 3: Utilities

*source: own elaboration

Figures 2 and 3 show the profitability rates for the business sector Financial services and Utilities, where the oscillating trend of each indicator is observed separately over 2015-2017 and not as ascending as we expected. Within the Financial Services sector, all the 8 banks included show an oscillating trend of the indicators as follows in 2016, there is a decrease in the profitability of the activity compared to year 2015, followed by an increase in 2017. Also, the highest values it registers them for $\mathrm{RCH}$, which reaches about 25\% in 2017, suggesting that the business sector is characterized by a high capacity to obtain profit after calculating all operating costs. The increase in the rate of gross and net commercial profitability related to the operating activity relative to the turnover reflects a positive state and occurs when the dynamics of the absolute profitability indicators outweigh the dynamics of the turnover, which we cannot say about the Utilities sector where negative values are recorded. 


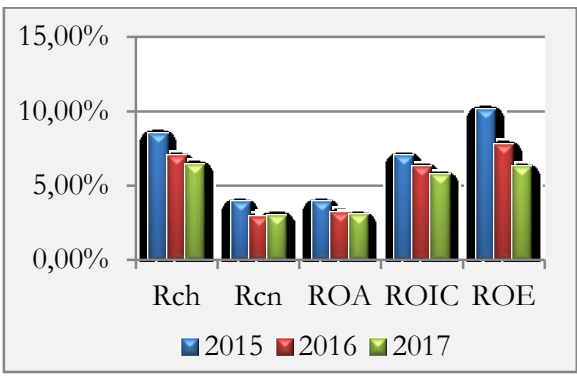

Figure 4: Consumer goods

*source: own elaboration

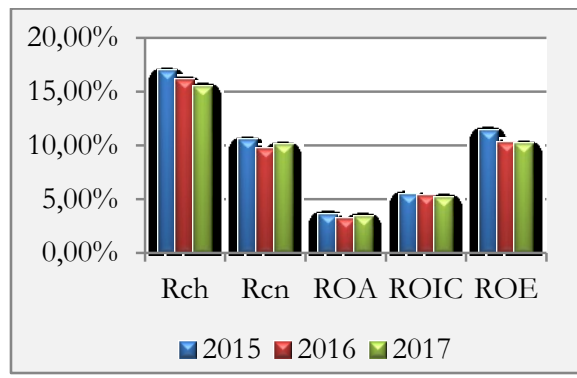

Figure 5: Transport

*source: own elaboration

In the Consumer goods and Transport sectors, there is clearly a descending evolution of most profitability indicators over 2015-2017, which shows that IR did not lead to an increase in the performance of companies. In general, the companies included in these two sectors show a descending or oscillating trend with the decrease of the rates of profitability rates in 2016 compared to 2017. One of the goals of IR is to explain to capital providersinvestors how the organization creates value over time [11], and here I consider one of the important indicators of profitability, ROE, which in the case of the two business sector (Figure 4 and Figure 5) shows a descending evolution. A declining ROE can affect the investments and it appears that IR did not lead to a better management of the sources of financing from the managers in order to increase value for investors.

I consider that the profitability of a company is influenced by the IR in the positive sense when the management aims to reach the financial but also non-financial objectives which is reflected on the financial performance because such an approach attracts investors, and not only, it attracts customers thus increasing sales, strengthening relationships with suppliers and the development of local markets that can lead to obtaining favorable purchase prices. All these elements will be reflected in the profitability of a company or a business sector.

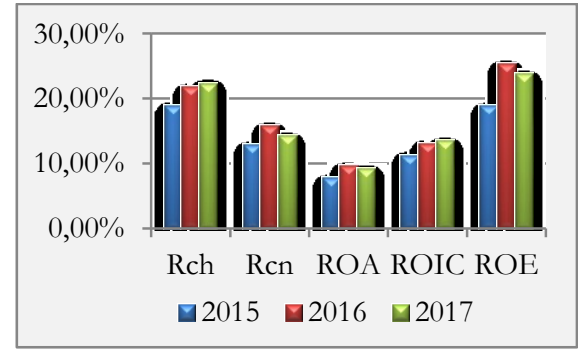

Figure 6: Tehnology \& Telecomunications *source: own elaboration

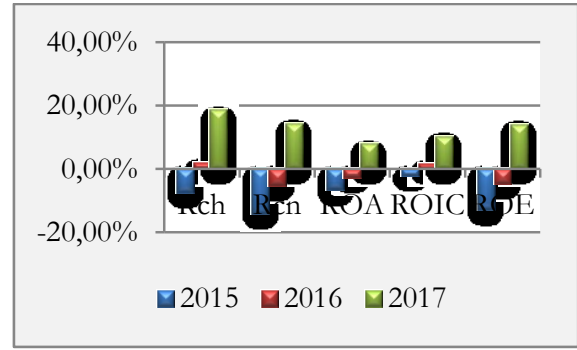

Figure 7: Mining

*source: own elaboration 
The profitability indicators in the sector of Technology \& Telecommunications are characterized mainly by an oscillating evolution but with high values between $7 \%-25 \%$. The economic profitability rendered by ROA and ROIC captures the efficiency of the material and financial means allocated for carrying out the activity of a company. In this case, the ROA is positioned between $7.78 \%-9.67 \%$ and the ROIC between $11.29 \%-13.56 \%$ that shows a high degree of remuneration of the capital employed in the companies activity, on the one hand, and on the other hand, it expresses the possibility for the remuneration of the risks assumed by the shareholders for the capital invested in companies without facing problems that increases the security of investments in this sector. Although ROE decreased in 2017 compared to 2016 year, it has high values compared to other business sector which can attract investors.

Analyzing the average result on each indicator separately from the Technology \& Telecommunications sector, I can say that in this area, the companies show a high profitability that could be influenced by the adoption of integrated reporting.

Figure 7 shows the situation of the profitability rates in the Mining sector, where negative values are recorded on all indicators, but shows an ascending trend, significantly improving the profitability of the companies in this sector in 2017 compared to the other reference years. It is the only business sector where we find an ascending trend in profitability and we can say that integrated reporting was one of the factors that influenced the performance of companies through the prism of an efficient and open management for innovation.

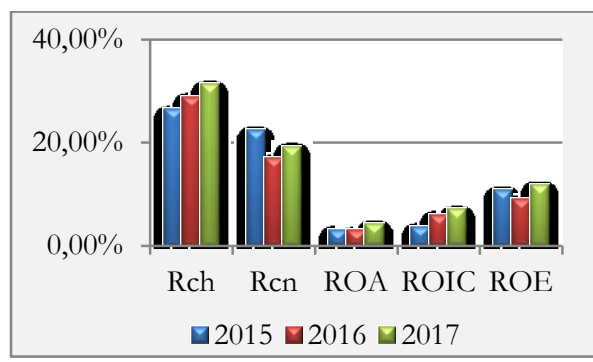

Figure 8: Oil\&Gaz

*source: own elaboration

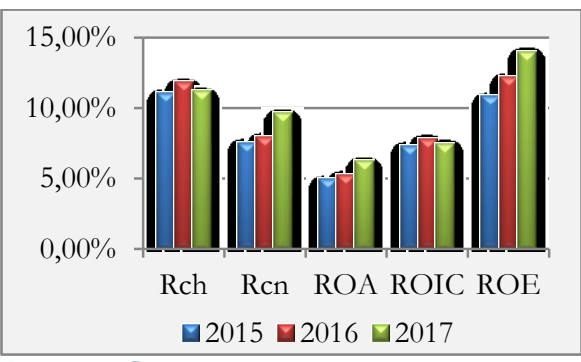

Figure 9: Chemicals

*source: own elaboration

In the Oil \& Gas sector I find an ascending trend in the case of the $\mathrm{RCH}$, with high values of up to $31.31 \%$ which reflects a high financial capacity of the companies in this sector to provide the necessary resources for investments. 
ROIC indicator has low values, above the minimum of $5 \%$ but does not reach an optimum level in order to be able to say that each company allows without problems the remuneration of shareholders and creditors.

The low values of the ROA and ROE indicators show an inefficient management of the operating activity respectively a retention from the investors on the business sector. The rest of the indicators are characterized by an oscillating trend.

The situation is another in Chemicals sector where the average of the rates of profitability shows an ascending trend for three of the rates and others with an oscillating tendency, having high percentage values in comparison with Oil \& Gas sector which shows a higher profitability in this business sector, but also, a more efficient management of the companies activity plus a security of their investments and their remuneration. For any company, it is of interest to know the financial structure with which it can carry out a profitable activity, as well as to know the level of indebtedness to which it can appeal, so that it does not reflect negatively on its financial profitability, therefore it is very important to position the ROE indicator at a optimum level. The situation is similar in the Industrial sector, shown in figure 10. In the Construction \& Material sector (figure 11) we can see the descending trend of the rates of profitability between 2015 to 2017 s, which shows us that the IR did not lead to a better management of the activity of the companies in this sector so that the profitability will increase from in the year.

The size of the economic profitability rate plays a decisive role for the management of a company in establishing the short and long term financing method. All the capital advanced in the activity of a company must be remunerated but, unlike the own capital (remunerated in order to obtain a profit), the borrowed capital must be remunerated regardless of the company's results. To ensure the financing needs are met, it will have to resort to obtaining new loans.

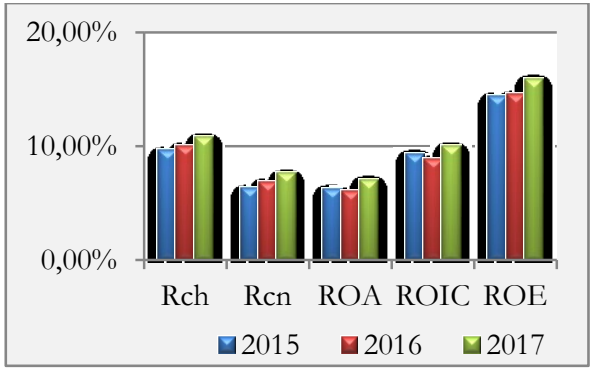

Figure 10: Industrial

*source: own elaboration

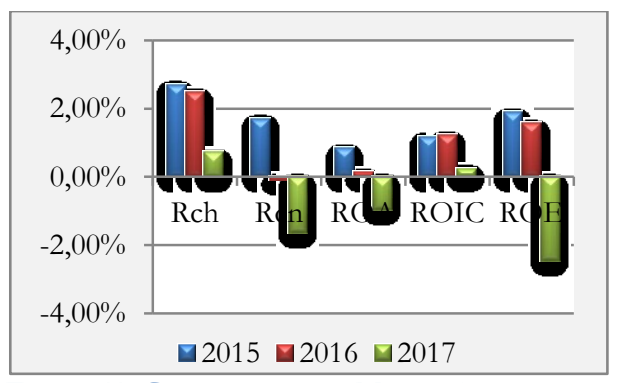

Figure 11: Construction \& Material *source: own elaboration 
Figure 11 shows that the results obtained, both from exploitation and the net result, do not amount to the level of invested or advanced capital and IR should be used by managers as a tool to ensure a balance for the company in itself, and for all other parties involved.

\section{Discussions}

Following the analysis of the companies performance from the ten business sectors, I noticed that the IR is not an important factor that would influence their profitability rates. IR was not understood and adopted in the same way by each company, therefore there are differences between the profitability rates of the companies in the all business sectors, implicitly between them. IR was not understood and adopted equally by each company, so there are differences between the profitability rates of companies in the 10 sectors, implicitly between them. I believe that IR, being a newer concept, needs more time to contribute by improving the results of companies, which will later stand out in each sector of activity.

This research contributes to the scientific literature by presenting the link between IR and the performance of a company, given that there is not enough research to clarify this topic.

The limits of this research are the analyzed time period and the sample size. Future research may include larger samples as a number of companies and as a number of financial exercises, as well as performance analysis through other indicators.

\section{Conclusions}

The results of my research showed that IR does not constitute a major influence factor on the financial situation of a company, in order to improve it from year to year. Therefore, I cannot validate and generalize the hypothesis that IR leads to the increase of the profitability of the companies, implicitly of their performance because within the 10 business sectors analyzed there are mainly oscillating and descending trends of the profitability rates, finding in a very small proportion, ascending trends ( for example Mining). This situation can be determined by a faulty management that did not correctly implement the concept of IR and that did not help to understand the concept of integrated thinking, so as to improve the financial performance, but also non-financial. My results support the opinion of [16] that managers of a company must adopt a culture based on sustainability and not focus only on financial objectives. 
They should avoid the formal adoption of integrated reporting and be aware of the boomerang effect resulting from the publication of a qualitative integrated report but which does not yet meet the expectations of the stakeholders. It should also avoid using this tool as a commercial policy, viewed from a philanthropy perspective and disconnected from the company's management. Therefore, if financial capital providers remain too focused on short-term financial performance, this may prevent an organization's ability to implement the fundamental business model changes needed to reorient the organization toward creating short, medium and long term value, which is fundamental to IR.

Management should act as a unitary whole and encourage IR implementation by educating staff, firstly, by introducing the concept of integrated thinking, possible things through training courses meant to drive the company's activity for the purpose of integrated reporting. From my point of view, it is clear that integrated reporting is an innovative management tool, anchored in the present economic context that used properly influences the performance of a company.

\section{Acknowledgements}

This work is supported by project POCU 125040, entitled "Development of the tertiary university education to support the economic growth - PROGRESSIO", co-financed by the European Social Fund under the Human Capital Operational Program 2014-2020

\section{References}

[1] Almăşan A, Circa C, Dumitru M, Guşe RG, Mangiuc DM. Effects of Integrated Reporting on Corporate Disclosure Practices regarding the Capitals and Performance. Amfiteatru Economic; 2019 August; 21(52): 572-589. DOI: 10.24818/EA/2019/52/572.

[2] Beretta V, Demartini C, Trucco S. Does environmental, social and governance performance influence intellectual capital disclosure tone in integrated reporting?. Journal of Intellectual Capital. 2018 December; 20(1): 100-124. DOI:10.1108/JIC-02-2018-0049.

[3] Bîrsan M. Analiza economico-financiară: instrument în managementul performant al firmei. Bucharest: Didactic and Pedagogical Publishing Ltd; 2013.

[4] Botez D. Raportarea integrată- sfârşit sau un nou început pentru raportarea financiară?, Financial Audit, 2013 February; 2(98): 23-29. 
[5] Burcă V, Mateş D, Bunget OC. Empirical Research on Identifying Main Drivers Leading to Integrated Reporting Framework Implementation. The case of European Region. The Romanian Economic Journal; 2018 December; 70: 52-72.

[6] Cheng M, Green W, Conradie P, Konishi N, Romi, A. The International Integrated Reporting Framework: Key Issues and Future Research Opportunities. Journal of International Financial Management \& Accounting. 2014; 25(1): 90-119. doi:10.1111/jifm.12015.

[7] Clayton AF, Rogerson JM, Rampedi I. Integrated reporting vs. sustainability reporting for corporate responsibility in South Africa. In: Szymańska, D. and Środa-Murawska, S. editors, Bulletin of Geography. Socio-economic Series. Toruń: Nicolaus Copernicus University. 2015; 29: 7-17. DOI: http://dx.doi.org/10.1515/bog-2015-0021.

[8] Druckman, P., Fries, J. Integrated Reporting: The Future of Corporate Reporting?. In Eccler, R., Cheng, B., and Saltzman, D., editors. The Landscape of Integrated Reporting. Reflections and next steps. Harvard. 2010: 81-85.

[9] Eccles, G. R., Armbrester, K. Two disruptive ideas combined: Integrated Reporting in the Cloud. IESE Insight. 2011; 8: 13-20. Available from: https://www.hbs.edu/faculty/Pages/item.aspx?num=40619.

[10] Eccles, G. R., Krzus, M. P., Ribot, S. The Integrated ReportingMovement, Meaning, Momentum, Motives, and Materiality. Wiley and Sons Inc. New Jersey. 2015.

[11] IIRC. The International IR Framework. 2013. Available from: http://integratedreporting.org/wp-content/uploads/2015/03/13-12-08the-international-ir-framework-2-1.pdf.

[12] IR Examples Databas, Available from: http:// examples.integratedreporting.org/home.

[13] Loprevite S, Ricca B, Rupo D. Performance Sustainability and Integrated Reporting: Empirical Evidence from Mandatory and Voluntary Adoption Contexts. Sustainability. 2018 April; 10(5): 1351. DOI: $10.3390 /$ su10051351.

[14] Mervelskemper L, Streit D. Enhancing Market Valuation of ESG Performance: Is Integrated Reporting Keeping its Promise? Enhancing Market Valuation of ESG Performance. Business Strategy and the Environment. 2017 May; 26(4): 536- 549. DOI: 26. 10.1002/bse.1935.

[15] Stubbs, W., Higgins, C. Stakeholders' Perspectives on the Role of Regulatory Reform in Integrated Reporting, Journal of Business Ethics. 2018 February; 147(3): 489-508. DOI: 10.1007/s10551-015-2954-0.

[16] Vitolla F, Raimo N, Rubino M. Apreciations, criticisms, determinants and effects of integrated reporting: A systematic literature review. 
Simona-Maria TANASĂ (BRÎNZARU) | Lumen Proceedings 13 | NCOE4.0 2020

Corporate Social Responsibility and Environmental Management. 2019 February; 26(2): 518-528. DOI: 10.1002/csr.1734. 